特集：振動による行動制御と害虫防除

短 報

\section{振動が誘発するアカマダラケシキスイ (コウチュウ目：ケシキスイ科）幼虫の 逃避行動}

\author{
貴志 学 ${ }^{1, *, \uparrow} \cdot$ 高梨 环磨 $^{2}$ \\ ${ }^{1}$ 和歌山県果樹試験場うめ研究所 \\ ${ }^{2}$ 国立研究開発法人森林研究・整備機構森林総合研究所森林昆虫 \\ 研究領域
}

Escape Behavior Induced by Substrate-borne Vibrations in Larvae of the Sap Beetle, Phenolia (Lasiodites) picta (Coleoptera: Nitidulidae). Manabu $\mathrm{KISHI}^{1, *, \dagger}$ and Takuma TAKANASHI ${ }^{2}{ }^{1}$ Japanese Apricot Laboratory, Wakayama Fruit Tree Experiment Station; 1416-7 Higashihonjo, Minabe, Wakayama 645-0021, Japan. ${ }^{2}$ Department of Forest Entomology, Forestry and Forest Products Research Institute; Tsukuba, Ibaraki 305-8687, Japan. Jpn. J. Appl. Entomol. Zool. 63: 150-154 (2019)

Abstract: We demonstrate that vibrations carried in a food substrate induced escape behavior in the larvae of the sap beetle pest, Phenolia (Lasiodite) picta (MacLeay) (Coleoptera: Nitidulidae), which infests Japanese apricot fruits. Accelerations of continuous vibrations from 8 to $32 \mathrm{~m} / \mathrm{s}^{2}$ at a frequency of $120 \mathrm{~Hz}$ within $30 \mathrm{~min}$ induced escape behavior in $60 \%$ of larvae. Pulsed vibrations of 1-s duration at intervals from 1 to $29 \mathrm{~s}$ induced escape behavior in $40-50 \%$ of larvae at $120 \mathrm{~Hz}$ and 8 or $16 \mathrm{~m} / \mathrm{s}^{2}$. Our findings suggest that the application of vibrations to a food substrate has a potential for removing larvae from the food by inducing escape behavior.

Key words: Phenolia (Lasiodites) picta; vibration; escape behavior

逃避行動は昆虫が捕食者による攻撃といった生存の危険を回 避する生得的な行動であり，様々な物理刺激がトリガーとなって いる (Ruxton et al., 2018). 例えば, ワモンゴキブリ Periplaneta americana (L.) やフタホシコオロギGryllus bimaculatus (DeGear) は腹部末端にある尾葉で空気の流れである気流を感知し，逃避 行動を引き起こすことが知られている（ワモンゴキブリ：Camhi et al., 1978; フタホシコオロギ: Kanou and Shimozawa, 1984). またアワノメイガ Ostrinia furnacalis (Guenée) やキマエホソバ Eilema japonica japonica (Leech) は捕食者であるコウモリが発す る超音波に対して, 飛翔の停止や急旋回などの逃避行動を起こす (Nakano et al., 2013).

振動もまた昆虫が周囲の環境を把握する刺激として利用して
いることが明らかになりつつある（Cocroft and Rodriguez, 2005； Takanashi et al., 2019). 例えば, 捕食寄生者であるヒメコバチ科 Sympiesis sericeicornis Nees による寄主探索時の振動に対し寄主で ある潜葉性のホソガ科 Phyllonorycter spp. の幼虫は逃避や行動停 止等の反応を起こす (Djemai et al., 2001). また, キイロショウ ジョウバエ Drosophila melanogaster Meigen の幼虫は振動などの刺 激に対して複数の感覚受容によって逃避行動を起こすことが知ら れている (Ohyama et al., 2015).

地上徘徊性のアカマダラケシキスイ Phenolia (Lasiodites) picta (MacLeay) (コウチュウ目：ケシキスイ科) (以下，アカマダラ) の成虫も振動を捕食者等の危険を意味する信号として認識し, 歩 行による逃避行動以外に擬死や歩行を停止するフリーズ反応を起 こすことが明らかになっている（貴志・高梨, 2019). 本種の幼 虫も地面に落下した際やピンセットで接触するなどの刺激を受け た際，急速な歩行による逃避行動や腹部を腹側に屈曲させた姿勢 で停止する tonic immobility (TI), いわゆる擬死行動 (以下, 擬死) (Humphreys and Ruxton, 2018) が観察される.このような刺激に 対する幼虫の擬死は，同じコウチュウ目のヒラタシデムシ亜科の 1 種 Silpha obscura L., シロテンハナムグリ Protaetia (Potosia) cuprea F., オビカツオブシムシ Dermestes lardarius L. (Bleich, 1928), またクロマドボタル Pyrocoelia fumosa Gorham (大場, 2007) でも 外敵を回避するために行うことが知られている.さらにコク又ス トモドキ Tribolium castaneum (Herbst) の幼虫については, 擬死ま たは歩行行動の二者択一的な逃避行動が採られる (Miyatake et al., 2008).さらに，カブトムシ Trypoxylus dichotomus (L.) の蛹が蛹 室内で振動し, 基質である腐葉土に天敵のモグラに似せた振動を 伝わらせることで他個体にフリーズ反応を引き起こさせ, 蛹室の 破壊と侵入を防いでいるという報告がある（Kojima et al., 2012a, b).

一方で，アカマダラは幼虫，成虫ともに熟した果実を好み， ウメやモモの戋場では落下した果実内部に食入し採慨する（貴 志・松野, 2015).このような生態により完熟落下したウメ果実 を用いた梅加工品で本種が異物として問題となっていた。しかし 近年はウメ果実の水浸漬による除去処理が行われ, 本種が原因 となる異物混入の減少に大きな効果を上げている (中・間佐古, 2009)。 またウメ以外の食品においても, 異物混入の苦情のうち 4 分の 1 程度が製造工程で混入した昆虫による（伊藤ら，2010） との報告もある. 現在, 海外では穀物などの貯蔵管理において, 振動や音を用いてココクゾウムシ Sitophilus oryzae (L.) やコクヌ ストモドキなどの貯蔵害虫を検知し, 種類や密度を推定する技術 開発が進められている (Mankin and Hugstrum, 2012). しかし, 振

日本応用動物昆虫学会誌 (応動昆) 第 63 巻 第 4 号 : 150-154 (2019)

http://odokon.org/

*E-mail: kishi@hotmail.co.jp

†現在 和歌山県工業技術センター

${ }^{\dagger}$ Present address: Industrial Technology Center of Wakayama Prefecture (WINTEC), 60 Ogura, Wakayama, Wakayama 649-6261, Japan. 2019 年 5 月 7 日受領 (Received 7 May 2019)

2019 年 8 月 1 日登載決定 (Accepted 1 August 2019)

DOI: $10.1303 /$ jjaez.2019.150 


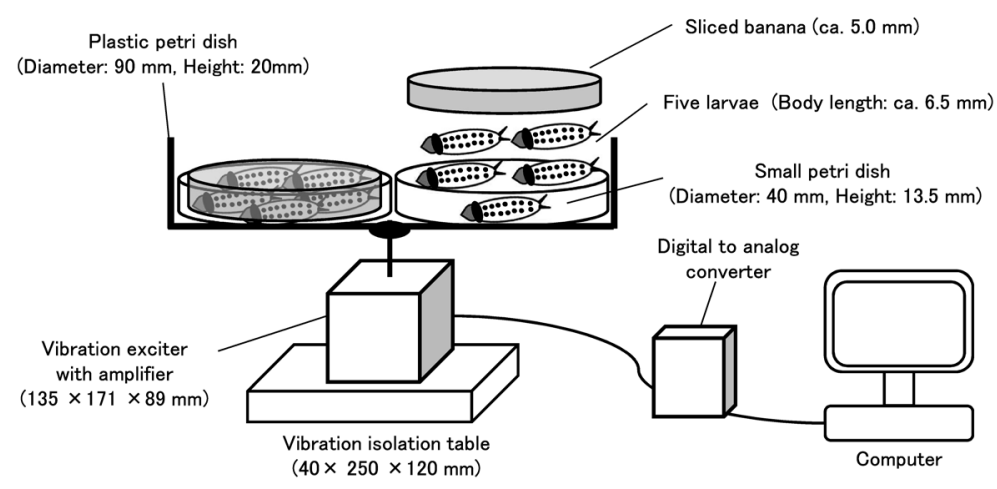

Fig. 1. Experimental systems for observing escape behavior induced by substrate-borne vibration in larvae of Phenolia (Lasiodite) picta. For each trial, five larvae were placed between a sliced banana at the bottom of a small petri dish.

動で害虫そのものを除去する技術に関する報告はない.

そこで本研究は，振動による食品内の昆虫除去技術開発の可 能性を検討するため，まず食品内に定着したアカマダラ幼虫の逃 避行動をどのくらいの振動の強さ (加速度) で誘発できるかを調 查した. 次にアカマダラ成虫の歩行抑制には連続した振動より も間欠した振動が効果的であった（貴志・高梨，2019）ことから， 加振により幼虫の逃避行動を誘発する際，間欠振動により効果を 向上できるかを検討した。

本研究の一部は, 内閣府 戦略的イノベーション創造プログラ 么 $(\mathrm{SIP})\lceil$ 次世代農林水産業創造技術」(管理法人：生研支援セン ター)によって実施した。

\section{材料扔よび方法}

\section{1. 供試虫および機材}

供試したアカマダラ幼虫は, 2016 年 9 月に和歌山県みなべ町 (和歌山県果樹試験場うめ研究所, $33^{\circ} 82^{\prime} \mathrm{N}, 135^{\circ} 34^{\prime} \mathrm{E}$ ) の研究戋場 において, 完熟落下したウメ「南高」果実から幼虫を採集した後, 3 齢 (終齢) 幼虫を 100 頭程度選別した。選別した幼虫は腐葉土 を 3 分の 2 程度満たした昆虫飼育ケース (幅 $17.5 \times$ 奥行 $11.8 \times$ 高 さ $11.8 \mathrm{~cm}$, ナカヤ化学産業株式会社, 東大阪市) に移動し, 餌 を与えず, 気温 $25 \pm 1{ }^{\circ} \mathrm{C}$, 人工照明条件下で 3 時間程度保持して から試験に用いた。

振動を発生させるためにアンプ内蔵小型加振器 (K2007E01, The Modal Shop 社，米国オハイオ州）を用い，除振台上の設置面 と本体振動部と接続した四小ネジ頭部が垂直になるように調整し た (Fig. 1)。ネジ頭部先端にプラスチックシャーレ（直径 $90 \times$ 高 さ $15 \mathrm{~mm}$, アズワン株式会社, 大阪) を両面テープ (SPS-12, ス リーエムジャパン，東京）で固定し，さらにシャーレの内側に 3 個の小型プラスチックシャーレ（直径 $40 \times$ 高さ $13.5 \mathrm{~mm}$, アズ ワン株式会社）を両面テープで固定した（Fig. 1)。 また試験に用 いたバナナ片は黒い斑点（シュガースポット）が果皮に現れ，甘 い香りが漂う状態のものを選別し, 試験直前に果肉のみを $5 \mathrm{~mm}$ 程度にスライスして用いた。

任意の振動条件となる周波数, 加速度抢よび休止時間はソフ トウェア (Quick DAQ, Data Translation 社, 米国マサチューセッツ 州)によりパソコン (Dynabook Qosmio T751/WTTD, 東芝クライ
アントソリューションズ株式会社, 東京) 上で設定し, 加振器の 内蔵アンプ間に接続したデータロガー（DT9837, Data Translation 社）から信号を出力して加振を行った. 振動条件はシャーレ中央 に加速度計 (352A24, PCB Piezotronics 社, 米国ニューヨーク州) を設置して, 上述のデータロガーとソフトウェア, パソコンを用 いて測定した．な扣加速度はゼロ・ピーク值 (片振幅值)である.

\section{2. 試験 1 アカマダラケシキスイ幼虫の逃避行動を起こす 振動}

幼虫をシャーレ上に直接配置，またシャーレに配置したバナ ナ上に配置した場合，多くの幼虫が加振前に逃避行動を示した. そこで幼虫をシャーレとバナナ片の間に挟み込むと多くが採餌を 開始し定着することを確認した，実際の観察では，幼虫 5 頭を小 型シャーレと小型シャーレ上に配置したバナナ片との間に挟み込 むように配置した，その後数分間静置し，全ての幼虫の定着を確 認した時点で加振を開始して反応を観察した，振動条件は，周波 数を $120 \mathrm{~Hz}$ とし, 4, 8, 16, 32 m/s $\mathrm{s}^{2}$ の加速度での連続した加振区を 設定した。 また振動を加えない無振動区を設定した。なおアカマ ダラ成虫の場合, $16 \mathrm{~m} / \mathrm{s}^{2}$ の加速度でシャーレ上での歩行が困難と なるが (貴志・高梨, 2019), 幼虫では $32 \mathrm{~m} / \mathrm{s}^{2}$ でも振動による観 察上の不都合は生じなかった.

逃避行動については，虫体の半分以上が小型シャーレの縁よ り露出した個体，またはバナナ片上に移動した個体を「逃避行動」 を示した個体とした，逃避行動を示した個体は確認後すぐにピン セットで別の容器に移し, 1 分毎にその数を記録した. 試験は人 工照明 (約 $2001 \mathrm{x}$ ), 気温 $28 \pm 1{ }^{\circ} \mathrm{C}$ の環境条件下で振動開始後 30 分間観察を行った。 反復は各条件でそれぞれ 9 回, 合計で 45 個 体行った.

\section{3. 試験 2 振動の休止時間がアカマダラケシキスイ幼虫の逃 避行動に与える影響}

振動の休止時間が逃避行動に与える影響を調査するため, 以 下の 5 つの条件を設定した，振動を与えない無振動区，持続時間 が 1 秒の振動パルスを与えた後にそれぞれ 1 秒, 4 秒, 9 秒の休 止時間を扎いた間欠振動区, また振動を与え続ける連続振動区 を設定した. 試験には試験 1 で十分な反応が確認された周波数 $120 \mathrm{~Hz}$, 加速度 $8 \mathrm{~m} / \mathrm{s}^{2}$ の振動を用いた。 反復は各条件でそれぞれ 9 回, 合計で 45 個体行った. 試験 1 において, 逃避行動を示し 
た幼虫の多くが試験開始 10 分以内であったため（Fig. 2), 試験 2 での観察時間は振動開始後 15 分間とした。 その他の条件は試験 1 と全て同じとした.

さらに長い振動の休止期間の影響を調査するため，周波数 $120 \mathrm{~Hz}$ ，加速度 8 および $16 \mathrm{~m} / \mathrm{s}^{2}$ で持続時間が 1 秒の振動パルス を与えた後にそれぞれ 29 秒の休止時間をおいた間欠振動区を設 定した，反復はそれぞれ 6 回，合計で 30 個体行った。このとき 観察時間を 30 分とし，その他の条件は試験 1 と同じとした. 比 較のため, 試験 1 で行った無振動区，また加速度 8 および $16 \mathrm{~m} / \mathrm{s}^{2}$ の連続振動区のデータを用いた.

\section{4. 統計解析}

加振条件が幼虫の餌からの逃避行動を起こすまでの時間に与 える影響を検出した。 ただし行動観察を 15 分（試験 2) または 30 分（試験 1 および 2) で打ち切ったため, まず Kaplan-Meir 法 による生存時間分析を行い，その後 Holm 法による多重比較検定 を行った.

また試験 1 と 2 の結果から，振動の加速度，休止時間および 加振の継続時間が幼虫の逃避行動に与える影響を検出するため,

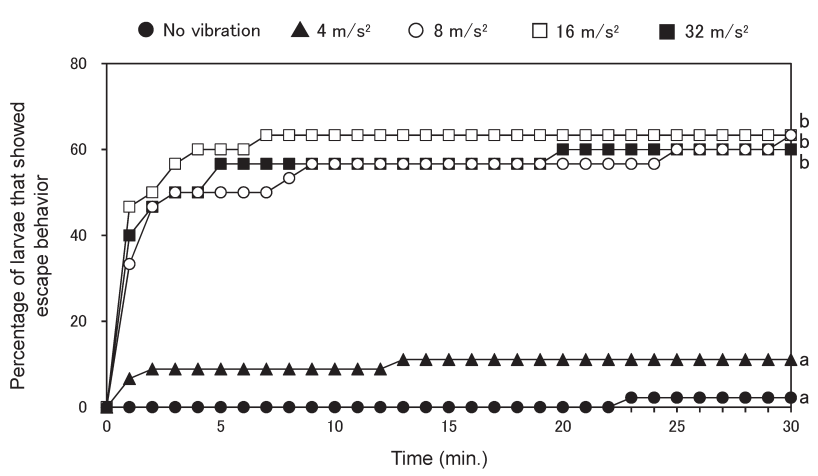

Fig. 2. Percentages of $P$. ( $L$. ) picta larvae responding to different accelerations of continuous vibrations at $120 \mathrm{~Hz}$. Lines followed by the same letter are not significantly different by the Holm method $(p>0.05)$ followed by survival analysis $(p<0.05)$, respectively.
逃避行動を示した個体を応答変数とし，振動の加速度，休止時間， 加振の継続時間 (15 分または 30 分) を説明変数，また観察数を offset 項として一般化線形モデル（GLM）にあてはめた．このと き, GLMに打ける応答変数の確率分布をポアソン分布と仮定す ると過分散が見られたため，疑似ポアソン分布を仮定した.

なお，本研究の全ての統計解析には統計ソフト $\mathrm{R}$ version 3.4.1（R Core Team, 2017）を用い，パッケージには EZR ver. 1.33 （Kanda, 2013）を使用した.

\section{結果と考察}

$120 \mathrm{~Hz}$ の各加速度 $\left(4,8,16,32 \mathrm{~m} / \mathrm{s}^{2}\right)$ の振動において, 加速度 $4 \mathrm{~m} / \mathrm{s}^{2}$ の連続振動区は逃避行動を示した個体の割合が低く, 無振 動区と比べて有意差が見られなかった. しかし $8,16,32 \mathrm{~m} / \mathrm{s}^{2}$ の連 続振動区の逃避行動を示した個体の割合は無振動区と比べ有意に 高かった（生存時間分析， $\chi^{2}=33.2, d f=4, p<0.001$ ； Fig. 2)。 . た加速度 8,16 打よび $32 \mathrm{~m} / \mathrm{s}^{2}$ の連続振動区の比較に打いて，逃 避行動を示した個体の割合に有意な違いは見られなかった（Fig， 2). 本試験で用いた振動の周波数は雨や風などによって発生し にくいため (Tsubaki et al., 2014), アカマダラ幼虫の逃避行動の 誘発は加速度 4 $8 \mathrm{~m} / \mathrm{s}^{2}$ の間でその加速度に依存した行動反応で あると考えられた。な朸虫の振動に対するフリーズ反応の閾 值は，成虫のフリーズ反応の閾值である $60 \mathrm{~Hz}$ 扎よび $120 \mathrm{~Hz}$ 1 2 m/s $\mathrm{s}^{2}$ (貴志・高梨, 2019) とほぼ同程度である. 振動を受容 する感覚器として，体節に内在する弦音器官や体表に点在する 感覚子が様々な昆虫で報告されており（Field and Matheson, 1998; Ohyama et al., 2015; Takanashi et al., 2019)，アカマダラ幼虫も同 様の器官で振動を感受し逃避行動を起こしているものと考えられ る.

振動の休止時間の逃避行動への影響については，加速度 $8 \mathrm{~m} / \mathrm{s}^{2}$ の間欠振動区 (休止時間 1 秒, 4 秒, 9 秒) は無振動区と比べ，逃 避行動を示した幼虫の割合は有意に増加した(生存時間分析, $\chi^{2}=21.5, d f=4, p<0.001$; Fig. 3$)$. さらに 29 秒の休止時間を与 えた加速度 $8 \mathrm{~m} / \mathrm{s}^{2}$ および $16 \mathrm{~m} / \mathrm{s}^{2}$ の振動でも, 同じ加速度で連続 した振動を与えた試験区と比べても, 逃避行動を示した個体の割

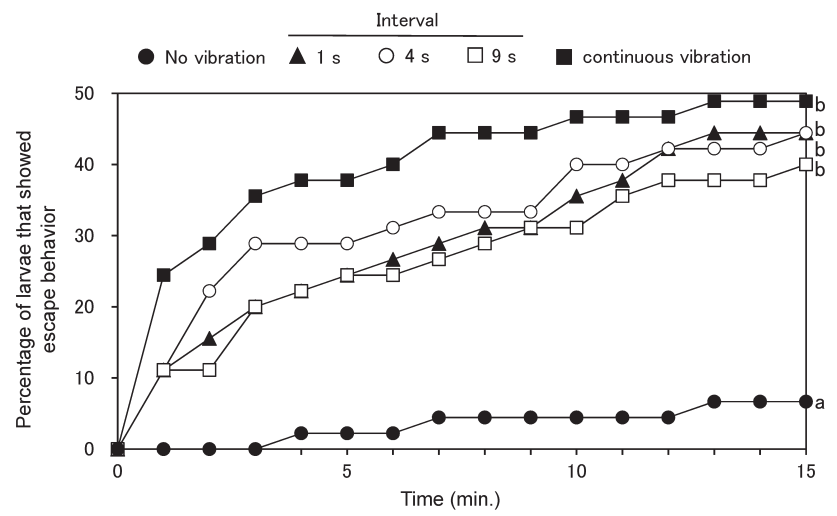

Fig. 3. Percentages of $P$. (L.) picta larvae responding to different intervals of pulsed vibrations with 1 -s durations at $120 \mathrm{~Hz}$ and $8 \mathrm{~m} / \mathrm{s}^{2}$. Lines followed by the same letter are not significantly different by the Holm method $(p>0.05)$ followed by survival analysis $(p<0.05)$, respectively. 


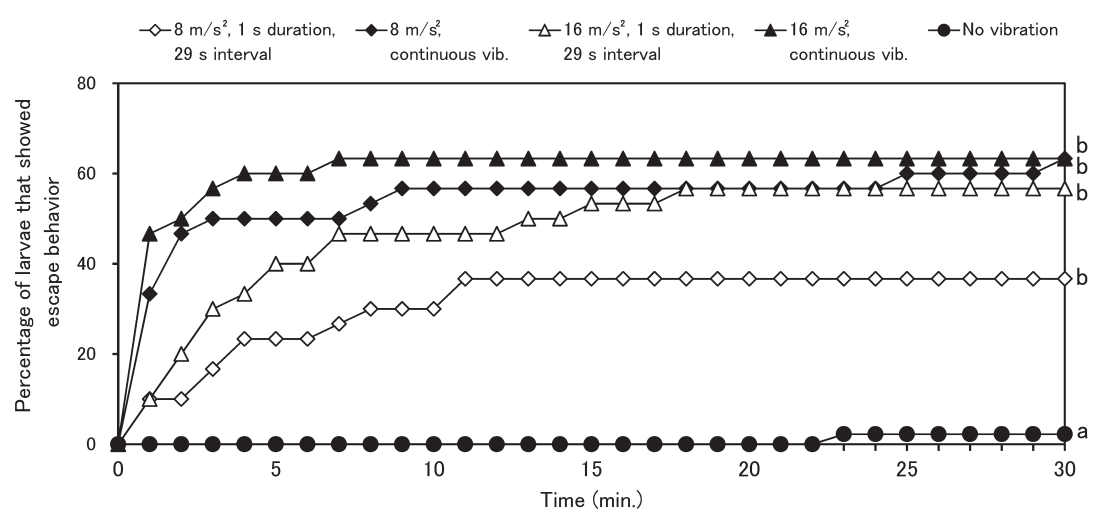

Fig. 4. Percentages of $P$. (L.) picta larvae responding to different accelerations of pulsed vibrations with 1-s durations and 29-s intervals or continuous vibrations at $120 \mathrm{~Hz}$. Lines followed by the same letter are not significantly different by the Holm method $(p>0.05)$ followed by survival analysis $(p<0.05)$, respectively.

合に有意な違いは見られなかった (生存時間分析, $\chi^{2}=27.2, d f=$ $4, p<0.001 ；$ Fig. 4).これらの結果は十分に逃避行動を誘発する 加速度の振動であれば，間欠振動を用いて幼虫の逃避行動を誘発 できることを示唆する。

GLMによる解析に打いて，アカマダラ幼虫の逃避行動の誘発 には振動の加速度に有意な影響を検出したが，休止時間に加えて 加振の継続時間による影響も検出されなかった (GLM, accelerations of pulsed vibrations $: z=3.25, p=0.005$, interval of pulsed vibrations : $z=0.86, p=0.40$, time to exposure of vibrations : $z=-0.37, p=$ 0.71).この結果はアカマダラ幼虫の逃避行動の誘発は, 振動の 加速度が重要であり, 間欠振動で加振することや加振の継続時間 を 15 分から 30 分に延長しても効果にあまり差が見られないこと を示唆する. 継続時間の短い間欠振動は, 振動に対する馴化 (貴 志・高梨，2019）を避けることが可能であり，またランニングコ ストが問題の 1 つとなる物理的防除の実用化において重要なもの と考えられる.

本実験では周波数 $120 \mathrm{~Hz}$, 加速度 $8 \sim 32 \mathrm{~m} / \mathrm{s}^{2}$ の連続振動で 15 分加振することで, アカマダラ幼虫の約 60\%（Fig. 2), また加速 度 $8 \mathrm{~m} / \mathrm{s}^{2}$ の間欠振動を用いることで約 $40 \%$ の逃避行動を誘発し た (Fig. 3,4). Djemai et al. (2001) では, Phyllonorycter spp. 幼虫 のうち捕食寄生者S. sericeicornis の振動に対し反応を示した個体 の 2 割強が逃避, 残りの約 7 割が行動停止を示していることか ら，本実験において振動刺激に対して逃避行動を示さなかったア カマダラ幼虫も果実内で行動停止や擬死を示していた可能性があ る.アカマダラ幼虫の刺激に対する逃避行動と行動停止の区別に ついては本実験では観察できていないため, 今後検討する必要が ある.

アカマダラ幼虫は水浸漬处理により 10 分で約 $80 \%, 23$ 分強で $100 \%$ のアカマダラ幼虫をウメ果実内から除去できる（中・間佐 古, 2009）ため, 今後は振動を用いた技術でこれらの数值に近づ ける必要がある。本実験では振動のみによる昆虫の除去効率は高 いものではなかったが，振動を用いた技術のメリットとして，他 の技術との併用が比較的容易な点が挙げられる. 実際にキイロ ショウジョウバエの幼虫では振動と同時に異なる刺激を感受する
ことで，逃避行動が強化されることが報告されている (Ohyama et al., 2015). したがって, 実用化にあたり今後は振動条件の最適化 や容器形状等の周辺技術の探索に加え, 光や温度による行動制御 (新井, 1976；Shimoda and Honda, 2013) などの物理的技術を組み 合わせ，除去の効果を増強する開発が必要であると考えられる.

\section{引用文 献}

新井哲夫（1976）応動昆 22：9-14. [Arai, T. (1976) Jpn. J. Appl. Entomol. Zool. 22: 9-14.]

Bleich, O. E. (1928) Berich. Wiss. Biol. A 10: 1-61.

Camhi, J. M., W. Tom and S. Volman (1978) J. Comp. Physiol. A 128: 203-212.

Cocroft, R. B. and R. L. Rodriguez (2005) Bioscience 55：323-334.

Djemai, I., J. Casas and C. Magal (2001) Proc. R. Soc. Lond. B 268: 2403-2408.

Field, L. H. and T. Matheson (1998) Adv. Insect Physiol. 27: 1-228. Humphreys, R. K. and G. D. Ruxton (2018) Behav. Ecol. Sociobiol. 72: 22. https://doi.org/10.1007/s00265-017-2436-8

伊藤真弓・小賏根惠子・金山彰宏 (2010) ペストロジー 25: 11-16. [Ito, M., K. Kosone and A. Kanayama (2010) Pestology 25: 11-16.]

Kanda, Y. (2013) Bone Marrow Transpl. 48: 452-458.

Kanou, M. and T. Shimozawa (1984) J. Comp. Physiol. A 154: 357365.

貴志 学・松野茂富 (2015) 応動昆 59：138-139. [Kishi, M and S. Matsuno (2015) Jpn. J. Appl. Entomol. Zool. 59: 138-139.]

貴志 学・高梨环磨 (2019) 応動昆 63: 13-16. [Kishi, M. and T. Takanashi (2019) Jpn. J. Appl. Entomol. Zool. 63: 13-16.]

Kojima, W., Y. Ishikawa and T. Takanashi (2012a) Biol. Lett. 8: 717-720.

Kojima, W., T. Takanashi and Y. Ishikawa (2012b) Behav. Ecol. Sociobiol. 66: 171-179.

Mankin, R. and D. Hagstrum (2012) In Stored Product Protection (D. W. Hagstrum, T. W. Phillips and G. Cuperus, eds. ). Kansas State University, Research and Extension, Manhattan, pp. 263-270.

Miyatake, T., K. Tabuchi, K. Sasaki, K. Okada, K. Katayama and S. Moriya (2008) Anim. Behav. 75: 113-121. 
中 一晃・間佐古将則（2009）農業および園芸 84：1106-1110. [Naka, K. and M. Kansako (2009) Agriculture and Horticulture 84: 1106-1110.]

Nakano, R., T. Takanashi, A. Surlykke, N. Skals and Y. Ishikawa (2013) Sci. Rep. 3: 2003.

大場信義 (2007) 横須賀市博物館研究報告 (自然科学) 54：5965. [Ohba, N. (2007) Bull. Yokohama City Mus. (Nat. Sci.) 54: 59-65.]

Ohyama, T. et al. (2015) Nature 520: 633-639.

R Core Team (2017) R : A language and environment for statistical computing. R Foundation For Statistical Computing, Vienna.
http://www.R-project.org/

Ruxton, G. D., W. L. Allen, T. N. Sherratt and M. P. Speed (2018) Avoiding Attack: The Evolutionary Ecology of Crypsis, Aposematism, and Mimicry. 2nd ed. Oxford University Press, New York. 320 pp.

Shimoda, M. and K. Honda (2013) Appl. Entomol. Zool. 48: 413-421. Takanashi, T., N. Uechi and H. Tatsuta (2019) Appl. Entomol. Zool. 54: 21-29.

Tsubaki, R., N. Hosoda, H. Kitajima and T. Takanashi (2014) Zool. Sci. 31: 789-794. 